\title{
The sustainability of ancient water control techniques in Iran: an overview
}

\author{
Mark Manuel $^{1}$ (D) Dale Lightfoot $^{2} \cdot$ Morteza Fattahi $^{3}$
}

Received: 20 April 2016/Accepted: 16 May 2017/Published online: 13 June 2017

(C) The Author(s) 2017. This article is an open access publication

\begin{abstract}
Qanats are a traditional source of water management that exists throughout much of the Middle East, and extending into North Africa, Spain and South Asia. In particular, they have played an important role in managing the supply of water throughout Iran for over two millennia in what is an arguably a sustainable manner. With water scarcity playing a prominent role in the modern world, qanats offer a practical, low cost solution to these issues. This paper looks at the early development of qanats in Iran, the important role they played in revolutionising the settlement systems and sustainability of communities in the past, and how they are now being reinvigorated to provide sustainable water in the present in Iran and other countries.
\end{abstract}

Keywords Qanat · Karez - Sustainable irrigation · Water management - Sustainability · Water scarcity $\cdot$ Archaeology

Mark Manuel

m.j.manuel@durham.ac.uk

Dale Lightfoot

d.lightfoot@okstate.edu

Morteza Fattahi

mfattahi@ut.ac.ir

1 Department of Archaeology, Durham University, Durham DH1 3LE, UK

2 Department of Geography, Oklahoma State University, Stillwater, OK 74078, USA

3 Institute of Geophysics, University of Tehran, 16 Azar Street Enghlab Avenue, Tehran, Iran 


\section{Introduction}

The management of water has had a profound effect on the development of complex societies across the world, from the simple digging of wells to the creation of highly complex networks of irrigation systems. Most early complex societies engaged in some form of water management techniques-from the household wells that characterise early cities in the Indus Valley c.2500 BC (Jansen 1991, pp. 147-160), to the annual capture of inundation waters along the Nile Valley (Hassan 1997). Indeed, it was seen as one of the primary drivers of early state formation, and often as part of a centralised and autocratic or despotic political arrangement (Wittfogel 1956, 1957). More recently, the development and ongoing management of water and irrigation systems can be seen as part of collaborative and co-operative social activities that help bind communities within the wider landscape. One example of this can be seen in Early Historic Sri Lanka, where hundreds of kilometres of canals and almost 30,000 tanks or reservoirs were created, enlarged and maintained by a sequence of kings and rulers (Brohier 1934). This complex hydraulic system was designed to capture and store the winter monsoon rains, and ensure the water remained accessible throughout the year. This endeavour enabled the agricultural carrying capacity of North Central Province to increase from 0.4 individuals, to 2400 per $\mathrm{km}^{2}$ (Coningham 1999, p. 24). Whilst largely abandoned from the 11-14th centuries AD onwards (Gilliland et al. 2013), the hydraulic network was reinvigorated by the British in the 19th and 20th centuries AD in order to repopulate the area (Brohier 2006 [1975], pp. 75-79). Six years of research at Anuradhapura suggests that the ongoing management of these hydraulic systems was not the job of the ruling kings who created them, but instead was devolved to monastic institutions in the hinterland (Coningham et al. 2013). Similar decentralised hydraulic management models exist within the water temple systems of Bali, where irrigation and the control of water is placed in the hands of farmer associations or subaks (Lansing 1987, p. 326).

Qanats are a traditional source of water management that exists throughout much of the Middle East, and extending into North Africa, Spain and South Asia (Fig. 1). Essentially they are subterranean tunnels excavated in order to transport large volumes of water from springs or water sources in upland areas to the dry, arid plains below. While seeming relatively simple, these tunnels can extend for tens of kilometres and require careful planning and construction (Beaumont 1968, 1971). The qanat tunnel is excavated from the base or outlet upwards into the area of water source - the mother well. During this process, vertical shafts are dug to provide ventilation and access for the immediate removal of spoil, and later on for cleaning (Fig. 2). The spoil from these access shafts creates the distinctive doughnut-shaped rings that characterise qanat lines. Qanats were in use by the start of the first millennium BC and archaeological studies report dates of 300-1000 BC for the earliest qanats in the UAE, Oman, and Iran (Labbaf Khaneiki 2000, Magee 2005, Al Tikriti 2002). Although OSL dating suggests that the oldest known qanat was constructed 2000 BC (Fattahi et al. 2014), still the exact date of the earliest qanats is unknown (see chapter in this volume for more on dating qanats). Within the arid and semi-arid regions of Iran they were the major source of perennial water until the mid-twentieth century when they became increasingly less important with the advent of modern engineering projects and, in particular, the advent of motorised pumping allowing access to deeper water sources (Beaumont 1968, p. 177).

With water scarcity highlighted as one of the leading issues facing the world in the future and Iran listed as "approaching physical water scarcity", focusing on issues of water 


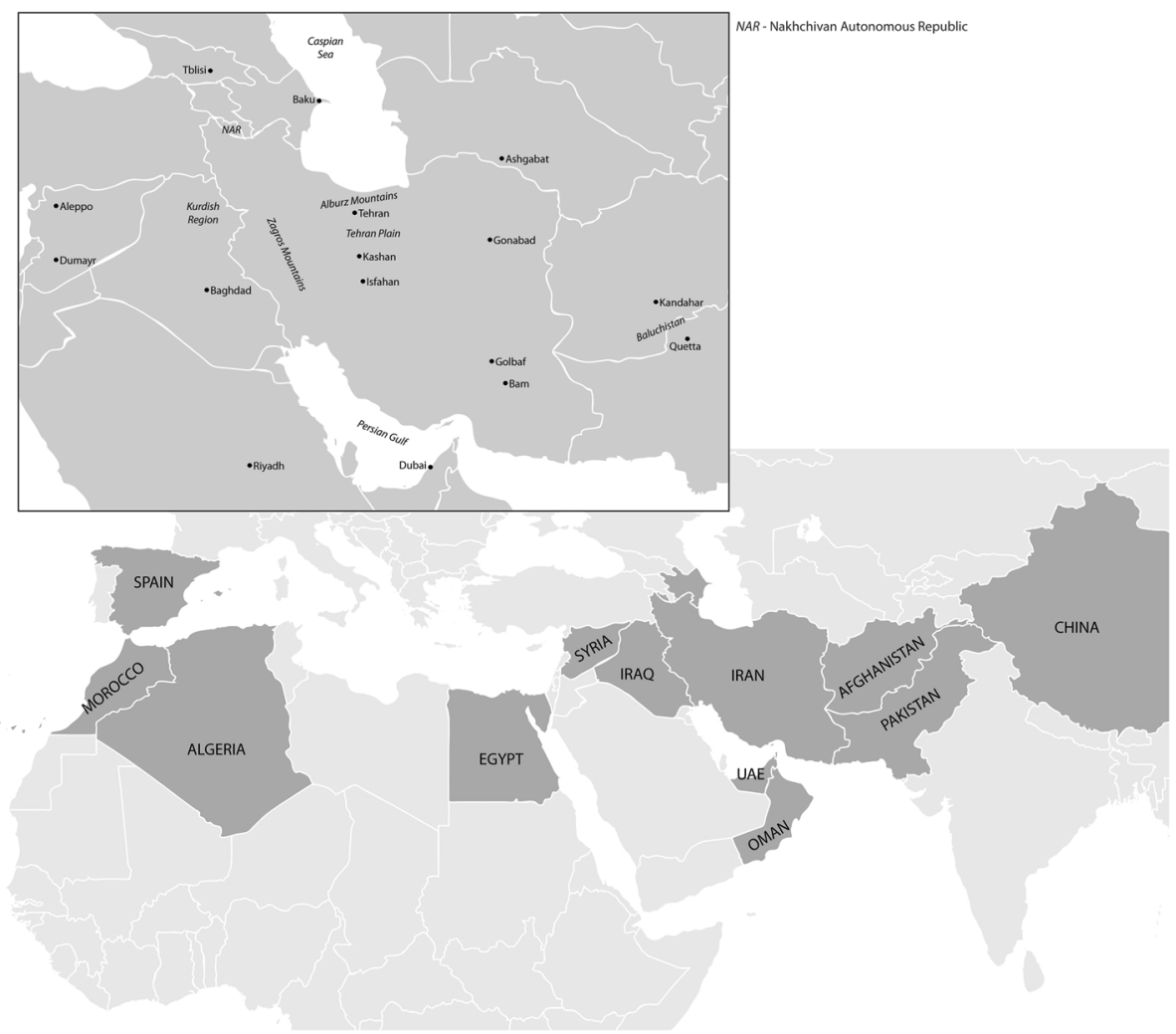

Fig. 1 Map of countries containing qanats as mentioned in the text, and the location of more specific case studies

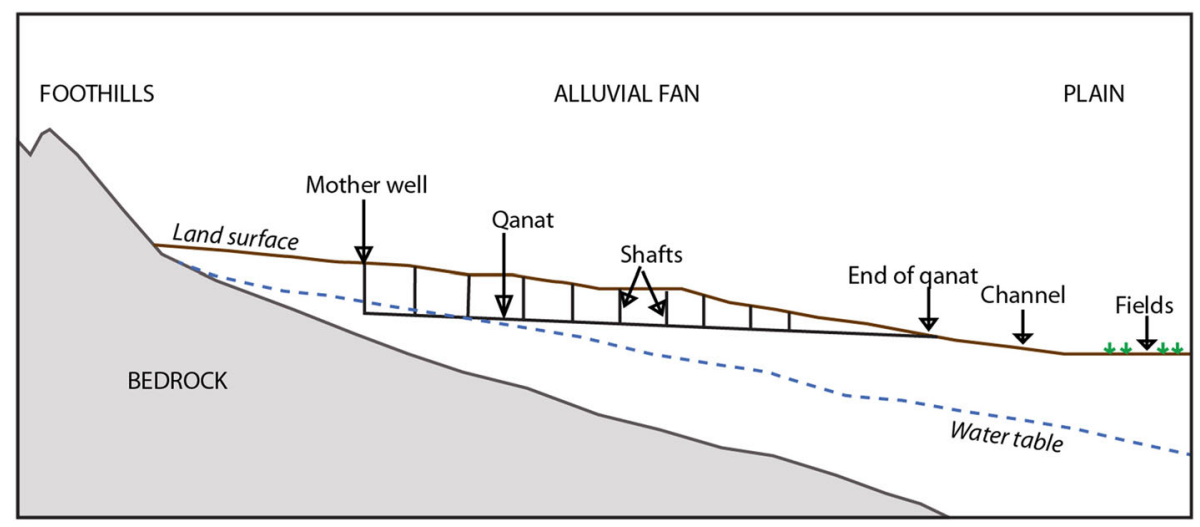

Fig. 2 Schematic of how a qanat transports water from upland to lowland areas (after Beaumont 1968, p. 171) 
management in the past and questions of sustainability are paramount (WWAP 2012; Manuel et al. 2014). Qanats offer a practical solution to problems of water supply due to their low evaporation rates during delivery and the relatively low cost and level of technology. Despite new irrigation projects, qanats have remained in service because they are, in most circumstances, sustainable - they can be used in perpetuity without damage to the environment, with limited depletion of the inputs on which it depends, or disruption to the socio-economic systems that maintain it. They deliver water through the force of gravity and do not require a source of power or fuel to operate. Qanat use encourages recycling and re-use of water at various stages along the linear system and qanats can only drain water from an aquifer that is naturally recharged; they do not pump water from an aquifer or draw down the water table. Because they do not reduce the capacity of an aquifer to retain water, they do not contribute to the compaction of aquifers and resulting surface subsidence and soil compaction as many pumped technologies have done. Furthermore, the social and economic systems that have maintained qanats for many centuries are aided by the social contracts and structures required to keep qanats healthy.

This paper looks at the early development of qanats in Iran, the important role they played in revolutionising the settlement systems and sustainability of communities in the past, and how they are now being reinvigorated to provide sustainable water in the present in Iran and other countries.

\section{Qanats as sustainable water management techniques in the Central Plateau}

The Central Plateau of Iran is a semi-arid desert surrounded by the Zagros Mountains to the west, the Alburz Mountains to the north, and by the upland areas of Baluchistan to the south and east. It incorporates the modern cities of Tehran, Qom, Isfahan and Kashan, as well as the low-lying salt plains of the Dasht-i-Kavir. Rainfall is seasonal predominantly falling between December and March, with averages between 220 and $340 \mathrm{~mm}$ at Tehran and Kashan (Ganji 1968, pp. 243-245). During these periods of rainfall and the subsequent snowmelt from the surrounding mountains, the alluvial fans within the Central Plateau become very fertile. However, during the harsh summer months, where rainfall is nonexistent and temperatures can regularly exceed $45^{\circ} \mathrm{C}$, agriculture is not possible without artificial irrigation.

This stark seasonality has been a driving force behind the development of complex societies within the Central Plateau, and the Tehran Plain in particular. The earliest evidence of settled communities in the area is found within the upland areas surrounding the Plateau - at sites such as Ganj Dareh, Ali Kosh and Choga Bonut-at around 8000 BC (Hole 2004). Several years of archaeological survey within the Tehran and Varamin Plains have demonstrated that the expansion or movement of communities from the upland and piedmont areas to the plain itself was a slow process (Fig. 3). By the Neolithic (6000-5200 BC) and Chalcolithic period (5200-3400 BC) a small number of settlements were established on the alluvial fan of the Jajerud River-one of the few that flows all year roundor, as in the case of Cheshmeh Ali, next to natural springs (Fig. 4) (Fazeli et al. 2004). Many of these sites show clear evidence of intermittent occupation, and the suggestion is that early communities shifted as did water courses (Manuel et al. 2014).

What is clear is that one of the major constraints on early settlement on the Tehran Plain was access to perennial water sources. Indeed, Roman Ghirshman, one of the early 


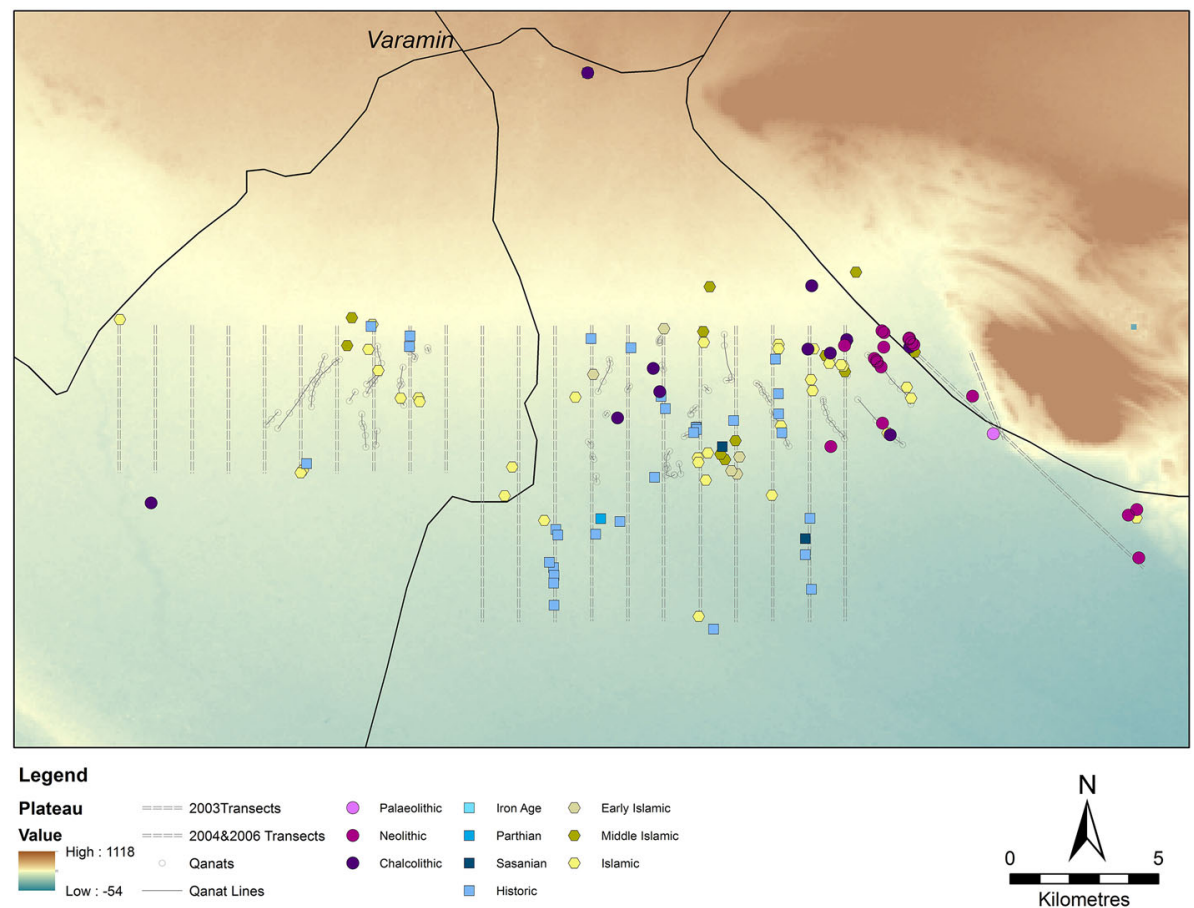

Fig. 3 Maps showing the development of settlement in Tehran Plain to the south of the modern city of Varamin from the Palaeolithic through to the Islamic period. Note how settlement is clustered along the junction of hill and plain at first, before expanding into the desert with the advent of qanat technology. (Topographic data is from NASA SRTM, and survey data is from the Tehran Plains Survey Project)

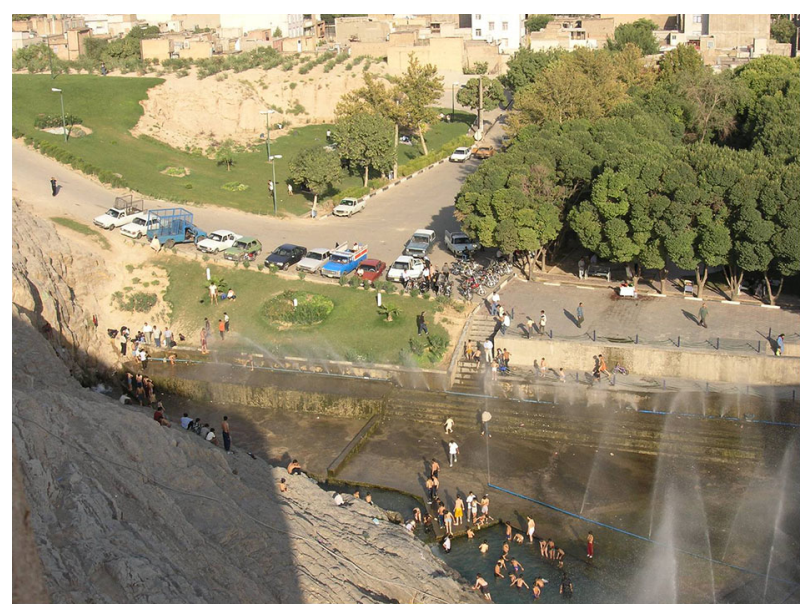

Fig. 4 The natural spring at Cheshmeh Ali, which is now a public park, demonstrates the importance of water to the location of early settlements in the Tehran Plain (photo by Robin Coningham) 
archaeologists who studied the Central Plateau of Iran, and excavator of Sialk and Cheshmeh Ali, stated that, "the physical aspects of the Plateau was harsh and austere. The oases were dispersed over difficult country, the population was sparse and scattered. As a result the urban revolution was retarded, and society continued in its prehistoric stage for centuries" (1954, p. 42). Excavation at Tepe Pardis has demonstrated the presence of a Neolithic (radiocarbon dated to 5220-4990 BC) irrigation channel, alongside evidence of shifting river channels running past the site (Fazeli et al. 2007; Gillmore et al. 2009). This early adaptation of the landscape to provide irrigation highlights the importance of water in sustaining settlements in the Central Plateau. However, Ghirshman's statement strikes a resonance, in that settlement in the area was heavily restricted until about 3000 years ago.

The situation changed with the introduction of qanat technology c.1000 BC which revolutionised people's ability to survive and subsist within the Central Plateau. By the mid-first millennium BC, during the Parthian and Sasanian period, settlement had dispersed across the plain and was no longer restricted by the shifting of water courses (Fazeli et al. 2007). However, many of the sites dating to this phase lacked key artefactual indicators associated with Sasanian or Parthian occupation elsewhere, suggesting that imperial presence in the area was weak, and that qanat construction was very much a localised prerogative. The near perennial flow of water provided by qanats allowed communities to concentrate population in one area and to open up larger tracts of land for agriculture (Manuel et al. 2014, pp. 57-58). Essentially, qanat technology reduced the impact of the Plateau's stark seasonality, allowing for sustainable occupation of the plains, and to utilise the rich alluvial soils. Some of the larger sites, such as Kaleh Navid, had several qanat lines terminating close to the village, and testify to the importance of water access. Indeed, population in the Central Plateau has boomed since its initial occupation, and is now home to some of Iran's major urban centres and agricultural regions.

Qanats are present throughout all of Iran, and some estimate that there are 22,000 functioning qanats transporting water for over $270,000 \mathrm{~km}$ of underground tunnels (Mostafaeipour 2010, p. 63), whilst other estimates place the number of qanats as high as 36,000 (Semsar Yazdi and Labbaf Khaneiki 2012b). The longest is at Gonabad in northeastern Iran, where a qanat extends for over $70 \mathrm{~km}$ in length, and transports water from a mother well sunk to a depth of $400 \mathrm{~m}$ (ibid.). Whilst this represents a huge investment in construction, and perhaps management, the majority of qanats in Iran are of a much smaller scale. Wilkinson et al. (2012) argue that most qanats are roughly 5-10 km in length, and that their origins are likely to be determined by local necessity as opposed to imperial or elite intervention (2012, pp. 169-170). In the Varamin Plain a study of 266 qanats showed lengths that varied between two and five kilometres in length, with the longer qanats at the desert margins (Beaumont 1968, pp. 172-175). Of the 266 qanats studied in the Plain, most were concentrated within the central part of the plain, where agriculture was concentrated, and scarcer along the alluvial cone and desert margins. Each village had access to only one qanat, with the exception of four villages (out of 250) which had access to two (ibid.: 172). Indeed, qanat lines, both active and defunct, can be seen converging on most Iranian villages, cities and towns, and highlight the importance that qanats played in creating the landscape of Iran today. Around the city of Bam there are an estimated 375 qanats, stretching $15 \mathrm{~km}$ from the city, with individual qanats running for up to $10 \mathrm{~km}$ in length. Before the 2003 earthquake they played a significant role in providing water to the city. Recognising the importance of qanats in sustainable water management, as well as a component of the regions social and cultural heritage, their rehabilitation was considered an important facet of post-disaster responses to the earthquake (Honari et al. 2006). As we will see later, this is being mirrored elsewhere in Iran, 
and further afield, as communities seek to re-engage with traditional and sustainable methods.

\section{The long-term use and reinvigoration of qanats}

Optically Stimulated Luminescense (OSL) dating of basin sediments in parts of Iran demonstrates that substantial amounts of surface water and heightened precipitation existed in areas that are now considered to be arid. Fieldwork at Dasht-e-Bayaz in the Nimbluk Valley in northeast Iran indicate lake highstand conditions at $<8.5 \pm 1.1 \mathrm{ka}$ ( 6500 BC) (Fattahi et al. 2010); and the South Golbaf palaeo-lake in southeast Iran indicates lake deposition was ongoing from at least $13.5 \mathrm{ka}(11150 \mathrm{BC})$ until the midHolocene (Figs. 5, 6). The South Golbaf palaeo-lake is likely to have spilled into the neighbouring Golbaf basin at $6.3 \pm 0.2 \mathrm{ka}$ (4500-4100 BC) (Walker et al. 2010; Fattahi et al. 2014). In general, this moister climate corresponds with a peak in moisture at $7.5 \mathrm{ka}$ (5500 BC) in the eastern Mediterranean (e.g. Bar-Matthews et al. 2003), and followed by gradually increasing aridity, with prolonged droughts at 5.2 and $4.2 \mathrm{ka}$ (3200 and 2200
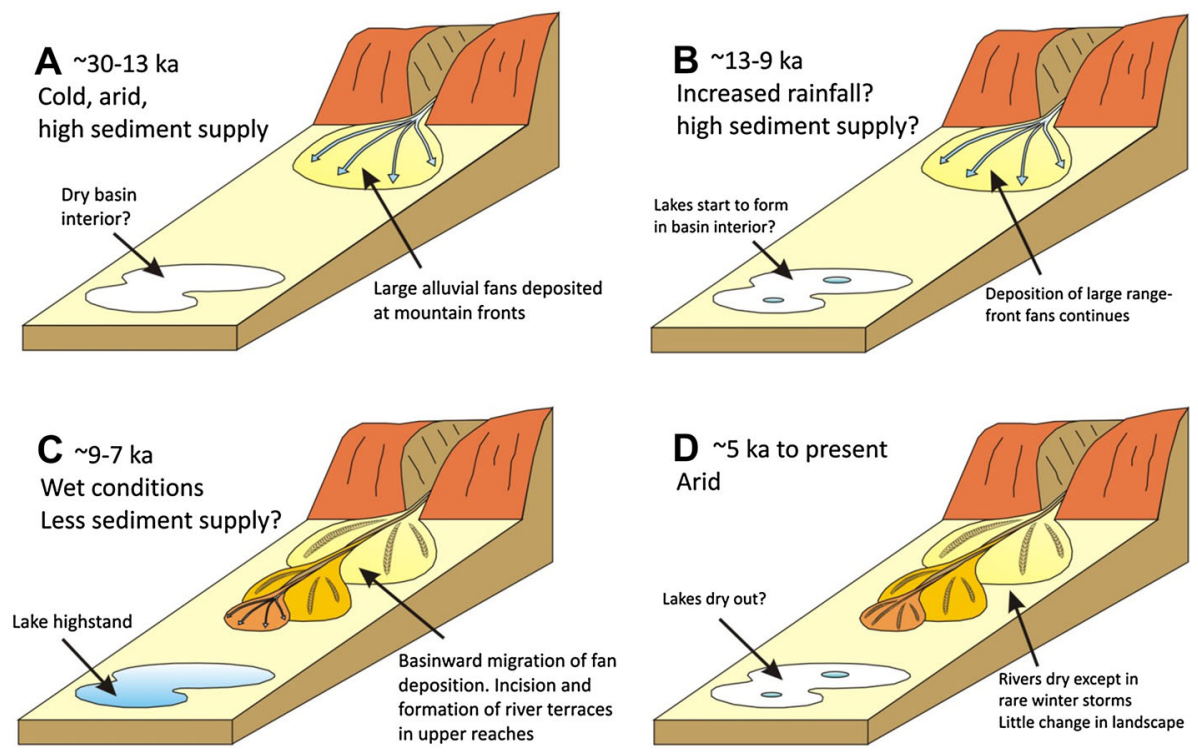

Fig. 5 A summary of the Last Glacial and Holocene palaeo-environmental changes suggested by the available age data in eastern Iran. a The deposition of large alluvial fans along the mountain range-fronts is likely to have started during the late glacial period with the production of large amounts of sediment in the cold and arid environment. b The range front fan deposition appears to have continued into the earliest part of the Holocene. The widespread fan deposition may be accompanied by an increase in the amount of precipitation combined with a plentiful supply of sediment. $\mathbf{c}$ The period from $\sim 9 \mathrm{ka}$ through to at least $\sim 7 \mathrm{ka}$ is marked by high lake levels indicating a relatively wet environment. Alluvial fan deposits at the mountain range-fronts are abandoned and incised due to a basinward migration of river-borne sediment deposition. The switch from sediment deposition to incision at the range-fronts may be a response to elevated rainfall coupled with a decreasing supply of sediment. d From the mid-Holocene it appears that river incision has slowed and the landscape has achieved roughly the form that it takes today. The slowing of landscape evolution may result from the onset of the arid climatic conditions that continue through to the present day (From Walker and Fattahi 2011) 


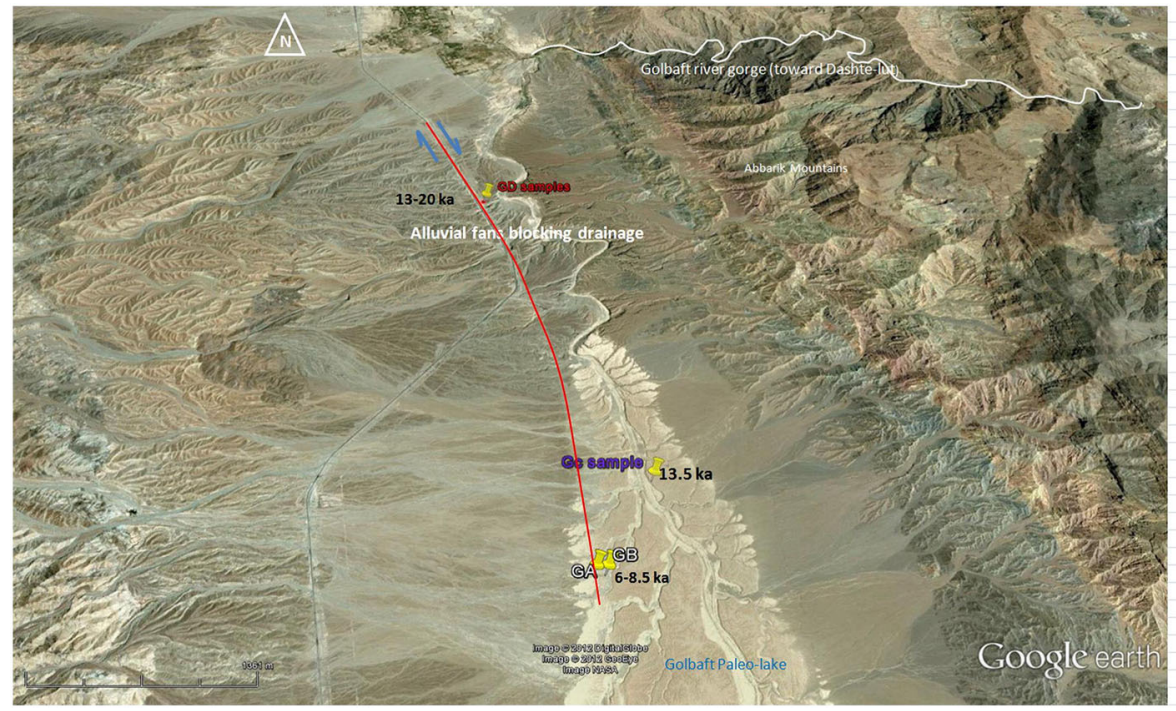

Fig. 6 The Golbaf basin in central Iran held substantial amounts of water from at least $13.5 \mathrm{ka}$ through $\sim 6.3 \mathrm{ka}$, as indicated by the thick homogeneous silt beds observed in exposures of sediment from the palaeolake interior (From Fattahi et al. 2014: Fig. 6)

BC). The latter of these droughts coincides with the collapse of the Akkadian Empire in Mesopotamia (Weiss et al. 1993; Cullen et al. 2000; deMenocal 2001), although this was in no means the primary driver of societal collapse (Wossink 2009).

Walker and Fattahi (2011) have suggested that increased aridity slowed the evolution of the landscape and had a detrimental effect on Bronze Age societies in eastern Iran. This mirrored a decline in a number of complex agricultural societies around the eastern Mediterranean and North African regions (e.g. Hassan and Stucki 1987; Weiss 2000; deMenocal 2001; Staubwasser and Weiss 2006). A scenario of regional aridification in the mid- to late Holocene is suggested by archaeological studies from southeast Iran (Adle 2006; Fouache et al. 2008). Lawler (2011) has suggested that Shahr-i Sokhta in southeast Iran was abandoned c.3000 BC after the Helmand Delta dried up and changed course. Excavations at Bam, a Bronze Age, predominantly agrarian, settlement twice as large as Shahr-i Sokhta, collapsed towards the end of the 3rd Millennium BC (Walker and Fattahi 2011). Following these urban abandonments people migrated to new places with access to surface water or springs. Adle (2006) and Fouache et al. (2008) argue that it was people in those areas where surface water was not readily available that spearheaded the development of qanat irrigation technology in order to re-establish agricultural societies some 1000 years later. The oldest absolute date for qanat construction suggest that this system was in use around 2000 BC in Dashtebayza, in northeast Iran (Fattahi 2015). A potential reason for a shift in the use of surface canals to qanat irrigation in the early part of the Archaemenid period $(2.5 \mathrm{ka} / 500 \mathrm{BC})$ at archaeological sites excavated near Sabzevar is attributed to a decrease in the availability of surface water (Fouache et al. 2010; Fig. 2) (Adle 2006; Fouache et al. 2008).

In the course of history the knowledge of qanat construction kept evolving. According to Semsar Yazdi and Askarzadeh (2007a) and Semsar Yazdi (2007b), it was an Achaemenid (550-330 BC) ruling that in case someone succeeded in constructing a qanat and 
bringing groundwater to the surface in order to cultivate, or renovating an abandoned qanat, the tax they were supposed to pay the government would be waived not only for themselves but also for up to five successive generations. Conversely, during the Seleucid (312-250 BC) and Parthian era (250 BC-AD 150) little imperial attention was paid towards qanats. During the Sassanid era (AD 226-650), the government supported the repair and construction of new qanats. Qanats continued to be utilised after the arrival of Islam (AD 621-1921), however, the invasion of Mongolian tribes in 13th century saw many qanats and irrigation systems fall into ruin. In the Safavid era (15th and 16th century) many new qanats, bridges, dams and water reservoirs were constructed; and the period of the Qajars (16th-18th century) is seen as the heyday of qanats. Tehran had a rich supply of groundwater and many qanats were constructed in Tehran, and qanat construction was supported throughout the country. However, at that time most of the qanats of the country belonged to landlords. Feudalism was the prevailing system in the rural regions, and peasants were not entitled to own lands they worked on. They had to pay rent for use of the land and water to the feudal lords. This allowed the feudal landlords to finance the high costs of maintaining qanats.

During the Pahlavi period (1925-1979), the process of qanat construction and maintenance continued. In 1959 a reformative program named the White Revolution was declared by the former Shah. One element of this was land reform, allowing individual famers to obtain ownership of land from their feudal landlords. However, the lack of concentrated finances resulted in the lack of upkeep and maintenance, and many of the qanats fell into disrepair. Furthermore, pumped wells had a negative impact on the qanats due to their overexploitation of the groundwater, and many qanats vanished forever.

In 1963 the Ministry of Water and Electricity (later renamed Ministry of Energy) was established in order to build dams and provide rural and urban areas of the country with sufficient water and electricity. At this period, the executive procedures of 19 dams began, out of which 13 came into action. In 1966 the parliament passed a law protecting groundwater resources, in which the Ministry of Water and Electricity was allowed to ban the drilling of deep and semi-deep wells wherever surveys show that the water table is dropping because of overpumping. This law, as well as the law of water nationalization that was approved in 1968 and eventually the law of fair distribution of water (passed in 1981 after the Islamic Revolution) finalised the definition of restricted and free areas for drilling. In restricted areas the drilling of wells (except for drinking and industry) was prohibited in order to prevent the continuous depletion of groundwater. As a result, qanats had a better chance to survive. After 1979, the Islamic Republic of Iran focused on the subject of the management of the surface and ground water. The provision for new 152 dams was identified, of which 72 came into action by 2005. The Jihad Sazandegi Organisation took responsibility for qanats and began to provide the users of qanats with funding for development. In 2000, an International Conference on qanats was held in Yazd to draw attention to qanats and qanat technology, and led to the creation of the International Center on Qanats and Historic Hydraulic Structures in Yazd and the establishment of the Qanat College in Taft.

Throughout the history of Iran, qanats played a critical role in the economy and socio political structures of the region both in urban and rural areas. Any negative impact on qanat systems could be recovered as soon as the crisis was over, but the present risks to qanats are huge. The over exploitation of groundwater resources can damage aquifers and surface sediments that cannot be easily recovered. 


\section{Reinvigorating Qanats as modern sustainable water management}

There are many more qanats in Iran than in any other country in the world, though many of the same challenges to qanat maintenance and sustainability have been faced by qanats and qanat users elsewhere. Throughout the broader region, qanat galleries have dried up, been damaged, or were abandoned through neglect, new channels have been added to regional inventories and there are several countries in the world where qanats are still an important part of local and regional water inventories managed by farmers, villages, and national ministries of water and irrigation. This is especially true in Iran, which has more qanats and more functioning qanats than any country in the world, and where exists the greatest variety of length, depth, form and features associated with qanats (cisterns, sluice gates, wind tunnels, cooling systems and water mills).

Because of their great utility, longevity, and sustainability, qanats have been refurbished and used for many centuries by private landowners and village cooperatives; by those who maintain water rights to a qanat. In spite of these advantages, qanats have often been viewed as backward and inefficient in comparison to modern solutions for water supply. Although they cannot keep pace with the needs of rapidly growing populations and industries, and they are sometimes abandoned in the rush to install newer equipment that can meet these growing needs, qanats are actively maintained in several countries to augment water supplies. This applies not only to Iran but to many settlements in Morocco, Algeria, northern Iraq and south-western India, and most notably in Oman, Afghanistan, Pakistan, China, Azerbaijan, where qanats are still widely employed as the primary or only source of irrigation and drinking water (Lightfoot, in press). Many governments in this group maintain lists of qanats as part of their national water and irrigation inventories and have funded qanat refurbishment programs or offered loans to private owners or village cooperatives to clean and maintain their qanats. In addition to these domestic efforts, many international organizations have orchestrated and funded qanat refurbishment. These programs usually involve surveys to assess a regional system of qanats and a refurbishment program to clean and rehabilitate select qanats.

As both a catalyst and consequence of these activities, many specialised conferences and workshops have been held over the past decade bringing together scholars and planners interested in the history and utility of qanats, and engineers and qanat specialists involved in cleaning and refurbishing qanats. New museums and training centres for the promotion and maintenance of qanats have also been established in China, Morocco, Azerbaijan, and Iran. In some of these cases, qanat inventory and refurbishment have been aided by groundwater modelling and geographic information systems (GIS), which are also used for continuing efforts to manage the water resources of a region (Ansari 2013; Khayyat 2009; Strikker et al. 2013). These national and international efforts in the inventory, promotion, and study of qanats have led to coordinated programs of qanat refurbishment in Morocco, Syria, Pakistan, Afghanistan, Azerbaijan, Iraq, and Iran.

A 1992 survey of qanats in the Tafilalt Oasis of southeastern Morocco counted 80 qanats constructed to provision 28 villages; yet only 19 of these channels were still flowing at the time of the survey (Lightfoot 1996a). Since that time, collaborative efforts by local cooperatives, NGOs and international groups like the Spanish Centro de Estudios Rurales y de Agricultura Internacional (CERAI) and the Japan International Cooperation Agency (JICA) have directed funding and labour toward the rehabilitation of the disused qanats around the oasis (Fig. 7). 


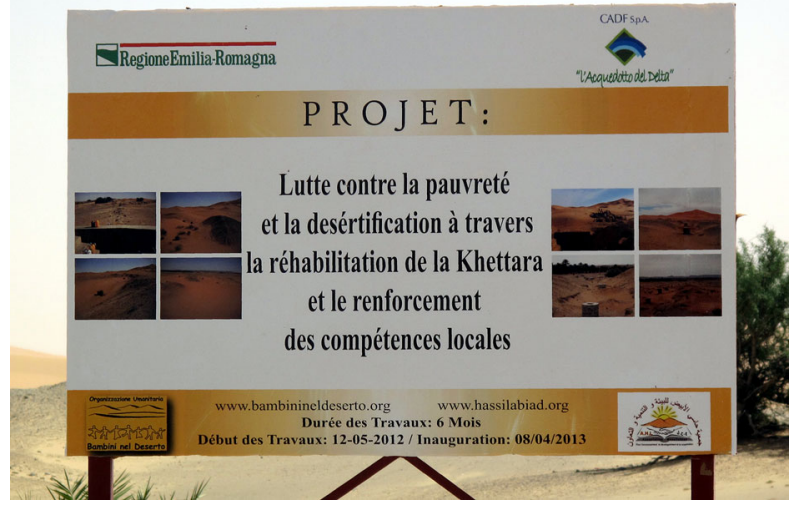

Fig. 7 Qanat (khettara) refurbishment promotion in Morocco

A survey of qanats across Syria was completed during 1993-1994 that documented 239 qanats across the country, $92 \%$ of which had ceased following since the introduction of pumped tube wells (Lightfoot 1996b). Guided by this survey, and using lessons learned during refurbishment of a qanat east of Aleppo in 2000, a Dutch scholar located 30 qanats in 2001 that were still in use, and targeted qanats in Shallalah Saghira, southeast of Aleppo, and Dumayr, east of Damascas for refurbishment. With funding from the Directorate General for International Cooperation and Ministry of Foreign Affairs of the Netherlands and the Swiss Development Cooperation Fund this team guided refurbishment efforts in 2001-2002 and produced a book from this experience that includes best practices in the design and implementation of refurbishment efforts (Wessels 2008).

In Pakistan the majority of qanats are found in Baluchistan, with over 800 recorded, and 60-80 percent of these in working condition (Chaudhry 2002; Kahlown 2012). Although most of these have been maintained by individuals and groups with water rights to the qanats, nearly 200 have been refurbished since the late 1980s. Collaborations between government ministries, the National Rural Support Programme (NRSP), U.S. Agency for International Development (USAID) and other NGOs aimed to clean qanats tunnels, cap qanat wells, and extend qanat channels and wells to tap deeper aquifers and thereby enhance water flow (Hussain et al. 2008; Kahlown 2012).

In Afghanistan, many of the 9370 qanats reported in a FAO/Ministry of Irrigation, Water Resources, and Environment survey were abandoned in historic times, though almost 6000 remained active at the time of this 2003 survey (Shobair 2012). Many have been damaged and abandoned since the 1970 s as a result of groundwater pumping and episodic conflict in the country. New laws have been enacted in recent years to protect qanats by restricting deep wells and any structure that can damage a qanat (Shobair 2012). Several qanat refurbishment projects have been funded and managed through the cooperation of the Afghanistan government and NGOs. These programs have focused on survey and strategic planning, and cleaning and repairing select qanats. More than $20 \%$ of the qanats in Afghanistan have benefitted from donor agencies (Shobair 2012).

Almost half of the 885 qanats still operating in Azerbaijan are found in the Nakhchivan Autonomous Republic, an exclave territory in the southwest of the country. Many of these began to dry up after 1960 because of negligence and the number of active qanats in Nakhchivan dropped to 288 until the International Organization for Migration (IOM) 
implemented a program to rehabilitate qanats in 2004, working with local government and stakeholders to survey and rehabilitate them (Semsar Yazdi and Labbaf Khaneiki 2012a). By 2011, IOM had rehabilitated 143 qanats in Nakhchivan with the help of local stakeholders and funding from the United Nations Development Programme (UNDP), European Commission (EC), Canada International Development Agency (CIDA), Swiss Agency for Development and Cooperation (SDC), and the U.S. State Department. This program was also aided by qanat specialists from UNESCO's International Centre on Qanats and Historic Hydraulic Structures who worked to incorporate modern methods and materials developed in their centre and associated Qanat College, and to expand, reinforce and waterproof these qanats (Semsar Yazdi and Labbaf Khaneiki 2012a). The IOM also began a qanat rehabilitation project in 2010 designed to renovate 20 qanats in the main part of Azerbaijan, with funding from the Korea International Cooperation Agency (IOM 2010; Lucie Dupertuis (IOM), personal communication). At the same time as these international efforts were underway, a new qanat was constructed for 90 households of Shishtebe village in Azerbaijan, funded by local water users and wealthy villagers living abroad and assisted with technical advice from IOM specialists (Lenk and Mehdiyev 2013).

UNESCO Iraq's science team has been working with local government authorities and community members to improve the supply of drinking and irrigation water in northern Iraq by helping restore traditional water systems in rural communities and providing training for sustainable water management (McHugh 2012). By 2007 UNESCO was aware that many qanats in northern Iraq were drying up and being abandoned and this was contributing to the de-population of villages where alternate sources of water were unreliable, too expensive, or non-existent. A field survey covering the three northern (Kurdish) governorates in Iraq was completed in 2009 under the auspices of UNESCO and documented 683 qanats; although 116 were still being used at the time of the survey, almost $70 \%$ of the qanats still functioning in 2004 had been abandoned since the onset of drought in 2005 (Lightfoot 2009) (Fig. 8). In 2010, armed with details from the survey, UNESCO teamed up with IOM (International Organization for Migration) and together they embarked on a two-year program of qanat refurbishment, targeting 22 qanats for

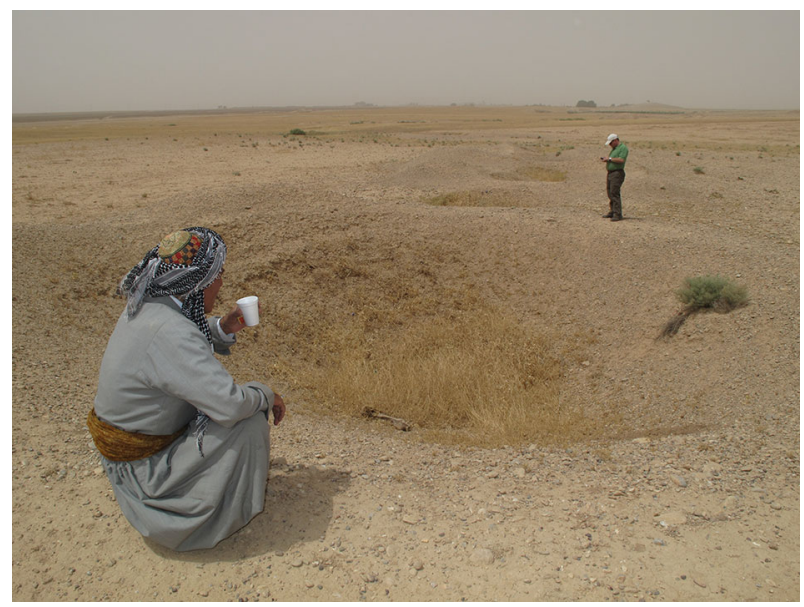

Fig. 8 Chain of wells of an abandoned qanat in Iraqi Kurdistan 
rehabilitation. Existing qanat tunnels were cleaned and, in some cases, new tunnels were extended further into the aquifers to enhance flow. New tunnel casing materials were added to reduce erosion and improve qanat performance. New features were also added to many qanats to make maintenance easier and to improve water supply, including new well casings, new outflow tunnels and canals, and new water taps and storage basins. On average, water discharge at qanats rehabilitated by UNESCO/IOM increased more than $60 \%$, and every community reported that the quality of water improved after rehabilitation (Walther 2011). As a result of these efforts, more than 1000 families have sufficient water to maintain their livelihoods (Fig. 9). In many cases, local people were hired to do much of the work and communities were trained in managing and refurbishing their qanats to ensure the sustainable flow of water (McHugh 2012).

Iran maintains more than 36,000 flowing qanats (Semsar Yazdi and Labbaf Khaneiki 2012b), far more than the combined 13,000 active qanats found elsewhere in the world, and greater even than the total number of qanats - fewer than 30,000 (mostly) relic featuresfound in the other 48 countries where they are known to exist (Lightfoot, in press).

For many centuries the moghani water specialists have preserved a specialized and valued trade in the construction and maintenance of tens of thousands of qanats in the region. With such a great number of qanats contributing so much to the national water supply, Iran maintains a long history of enacting laws that protect qanats and diverting

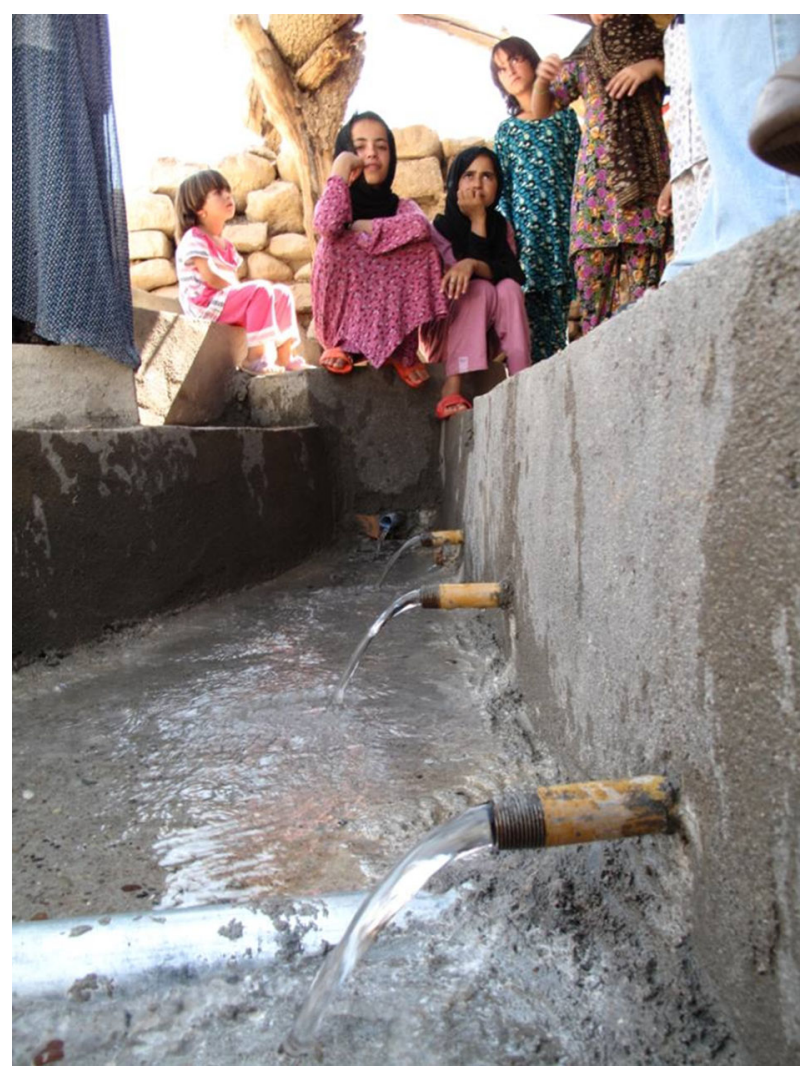

Fig. 9 Exit of the Kani Jinan qanat after restoration, Garazel, Iraq (photo by Lucie Dupertuis) 
national income to maintenance and refurbishment. Since the introduction of laws protecting against groundwater pumping in the 1960s, and the national workshops in the 1980s (Semsar Yazdi and Labbaf Khaneiki 2012c), 8000 qanats have been rehabilitated in Iran, representing almost $25 \%$ of those flowing today (Hussain et al. 2008). These domestic efforts have been aided through international collaborations between the government of Iran and UNESCO, which created the International Centre on Qanats and Historic Hydraulic Structures (ICQHS) in 2005. This active centre, with its affiliated Qanat College, has collected and disseminated information on qanats in the region and worldwide, sponsored research, preserved traditional knowledge, and trained a new corpus of workers on the use of new materials and techniques that are appropriate to maintaining and refurbishing qanats. ICQHS specialists are working not only to rehabilitate qanats in Iran, but have also organized and hosted a number of international conferences and training workshops and have sent specialists to aid qanat rehabilitation projects in neighbouring countries like Azerbaijan and Iraq. Qanat-irrigated agriculture in Kashan, in Isfahan Province, Iran has also been the focus of United Nations Food and Agriculture Organization preservation efforts (for water and tourism) since 2013 as part of their Conservation and Sustainable Management of Globally Important Indigenous Agricultural Heritage Systems (GIAHS) program (UNFAO 2014).

\section{Discussion and Conclusion}

Tens of thousands of qanats have been engineered, excavated, and maintained for centuries to augment water supplies from springs and wells and to bring a flowing stream of surface water to places that had no flowing water. Qanats remain important in several countries, even after many centuries of use, because they require little technology to operate and they are sustainable systems that have lasted. Nowhere have they been built in greater numbers, or maintained with such regularity, than in Iran, where emerged a dedicated class of labourers-the moghani-who trained others through the generations as skilled qanat builders to maintain the qanats of Persia and to expand this technology to surrounding regions. This symbiotic system of skilled labour and long-lived technology was made possible by the sustainability of the whole qanat enterprise.

Although qanats operate in a sustainable manner with their environment, they have been damaged and abandoned over the centuries as a result of earthquakes, droughts, wars, and social and technological changes that alter the labour supply; multiple factors that have impacted the socio-environmental context of the qanat system. In the modern era, it was the introduction of diesel and electrically-powered tube wells that has had the most immediate and adverse impact on the longevity of qanats. A qanat is only sustainable as long as the aquifer on which it depends is in balance. Pumped wells commonly withdraw more water from an aquifer than is naturally resupplied, resulting in falling water tables and qanats that are insufficiently supplied from their source wells. This, combined with long-term drought, can result in the abandonment of qanats, as we have seen in many parts of Iran and the broader region over the past decades.

As water scarcity becomes an increasingly pressing issue within the modern world, the reinvigoration of qanats can play an important role in supporting the sustainable use of water across what is a climatically, and often politically, unstable region. The relative simplicity of construction and management of the systems ensures that local communities can retain ownership of them. Increasing awareness of the role they can play is also clear 
from United Nations initiatives, and the creation of institutions such as the ICQHS and Qanat College in Iran. Qanat reinvigoration can act as a champion for other traditional water and resource management strategies globally. Furthering our archaeological understanding of qanats is also helping us to elucidate the date of origin, how they transformed the sometimes hostile landscapes of Iran and its neighbouring countries and how they can revitalise communities that reside there in the present day.

Acknowledgements The authors would like to express their gratitude to Julien Charbonnier and Kristen Hopper for organising The Qanat: Archaeology and Environment workshop at Durham University in October 2014, and for inviting us to contribute towards this special edition. Thanks also go to Durham University, the British Institute of Persian Studies and the British Foundation for the Study of Arabia for supporting the workshop. We would also like to thank the following people and institutions for their support in conducting fieldwork and research into the archaeology, geography and restoration of qanats: UNESCO, the International Organization for Migration, the British Institute of Persian Studies, the Iranian Cultural Heritage, Handicrafts and Tourism Organisation (ICHHTO), the Iranian Centre for Archaeological Research, the Sialk Archaeological Research Centre, the British Academy, the Institute of Geophysics and the Institute of Archaeology of the University of Tehran, Professor Robin Coningham, Professor Hassan Fazeli, Professor Gavin Gillmore, Professor Ian Simpson, Dr Ruth Young, Armineh Marghussian, Hingameh Ilkhani, Hossein Azizi, Dr Sayyed Taha Hasehmi, Dr Mohammad Gholam Nejad, Dr Seyed Mahdi Mousavi Koohpar, Dr Hassan Karimian, Dr Hayedeh Laleh, Dr Masoud Azarnoush, Dr Richard Walker, Dr Mohammad M Khatib, Dr Morteza Talebian, Professor Majid Nabi-Bidhendi, Casey Walther, Dr Idris Hadi, Dr Beriwan Khailany, Hawta Khatyyat, Lucie Dupertuis and Dr Randy Donahue.

Open Access This article is distributed under the terms of the Creative Commons Attribution 4.0 International License (http://creativecommons.org/licenses/by/4.0/), which permits unrestricted use, distribution, and reproduction in any medium, provided you give appropriate credit to the original author(s) and the source, provide a link to the Creative Commons license, and indicate if changes were made.

\section{References}

Adle C (2006) Qanats of Bam: and archaeological perspective. Irrigation system in Bam, its birth and evolution from the prehistoric period up to modern Times. In: Honari M et al (eds) Qanats of Bam. A multidisciplinary approach. UNESCO Tehran Cluster Office, Tehran, p 158

Al-Tikriti WY (2002) The south-east Arabian origin of the falaj system. Proc Semin Arab Stud 32:117-138

Ansari T (2013) Improvement management of foggara in the geographic information system (GIS). In: Proceedings of the first IWA workshop on traditional qanats technologies. Marrakech, Morocco, 24-26 October, 2013

Bar-Matthews M, Ayalon A, Gilmour M, Matthews A, Hawkesworth CJ (2003) Sea-land oxygen isotopic relationships from planktonic foraminifera and speleothems in the Eastern Mediterranean region and their implication for palaeorainfall during interglacial intervals. Geochim Cosmol Acta 67:3181-3199

Beaumont P (1968) Qanats on the varamin plain, Iran. Trans Inst Br Geograph 45:169-179

Beaumont P (1971) Qanat systems in Iran. Hydrol Sci J 16:39-50

Brohier RL (1934) Ancient irrigation works in ceylon. Ministry of Mahaweli Development, Colombo

Brohier RL (2006) [first published 1975]. The story of water management in Sri Lanka Down the Ages (food and the people). Sooriya, Colombo

Chaudhry, M. R. 2002. Water management in Balochistan. Unpublished paper. Lahore, Pakistan.

Coningham RAE (1999) Anuradhapura: The British-Sri Lankan Excavations at Anuradhapura Salgaha Watta 2. Volume 1: The Site. BAR (International Series) 824. Archaeopress, Oxford

Coningham RAE, Gunawardana P, Adikari G, Manuel MJ, Davis CE, Simpson IA (2013) Discussion. 459-478. In: Coningham RAE, Gunawardana P (eds) Anuradhapura volume III: the Hinterland. BAR International Series 2568. Archaeopress, Oxford

Cullen HM, deMenocal PB, Hemming G, Brown FH, Guilderson T, Sirocko F (2000) Climate change and the collapse of the Akkadian empire: evidence from the deep Sea. Geology 28:379-382

deMenocal PB (2001) Cultural responses to climate change during the late Holocene. Science 292:667-673 Fattahi M (2015) OSL dating of the Miam Qanat (KĀRIZ) system in NE Iran. J Archaeol Sci 59:54-63 
Fattahi M, Walker R, Khatib MM, Zarrinkoub M (2010) Optical dating of holocene lake-bed sediments from the Nimbluk plain, Khorasan, NE Iran: Implications for the Palaeo-environment of Iran. Presentation at the geological survey of Iran annual conference 2010

Fattahi M, Walker RT, Talebian M, Sloan RA, Rasheedi A (2014) Late Quaternary active faulting and landscape evolution in relation to the Gowk Fault in the South Golbaf Basin, SE Iran. Geomorphology 204:334-343

Fazeli H, Coningham RAE, Batt CM (2004) Cheshmeh Ali revisited: towards an absolute dating of the late Neolithic and Chalcolithic of Iran's Tehran Plain. Iran 42:13-24

Fazeli H, Coningham RAE, Young RL, Gillmore GK, Mahghsoudi M, Raza H (2007) Socio-economic transformations in the Tehran Plain: final season of settlement survey and excavations at Tepe Pardis. Iran 45:267-285

Fouache E, Cosandey C, Adle M, Casanova HP, Francfort Y, Madjidzadeh M, Tengberg M, Sajadi Z, Shirazi A, Vahdati A (2008) A study of the climatic crisis of the end of the third Millenium BC in Southeastern Iran through the lens of geomorphology and archaeology. Proceedings of the 10th annual symposium on Iranian archaeology. Bandar Abbas, Iran

Fouache E, Francfort H-P, Bendezu-Sarmiento J, Vahdati AA, Lhuillier J (2010) The horst of Sabzevar and regional water resources from the Bronze Age to the present day (Northeastern Iran). Geodin Acta 23:287-294

Ganji MH (1968) Climate. In: Fisher WB (ed) The Cambridge history of Iran volume 1: the land of Iran. Cambridge University Press, Cambridge, pp 212-249

Gilliland K, Simpson IA, Adderley WP, Burbidge CI, Cresswell AJ, Sanderson DCW, Coningham RAE, Manuel MJ, Strickland KM, Gunawardana P, Adikari G (2013) The dry tank: development and disuse of water management infrastructure in the Anuradhapura hinterland, Sri Lanka. J Archaeol Sci 40:1012-1028

Gillmore GK, Coningham RAE, Fazeli H, Young RL, Magshoudi M, Batt CM, Rushworth G (2009) Irrigation on the Tehran Plain, Iran: Tepe Pardis — the site of a possible Neolithic irrigation feature? CATENA 78:285-300

Hassan FA (1997) The dynamics of a riverine civilization: A geoarchaeological perspective on the Nile Valley, Egypt. World Archaeol 29(1):51-74

Hassan FA, Stucki BR (1987) Nile floods and climatic change. In: Rampino MR et al (eds) Climate: history. Van Nostrand Reinhold, Periodicity and Predictability, pp 37-46

Hole F (2004) Neolithic age in Iran. Encyclopaedia Iranica, Online Edition 20 July 2004, available at www. iranicaonline.org

Honari M, Salamat A, Salih A, Sutton J, Taniguchi J (eds) (2006) Qanats of Bam: a multidisciplinary approach. UNESCO Tehran Cluster, Tehran

Hussain I, Abu-Rizaiza OS, Habib MAA, Ashfaq M (2008) Revitalizing a traditional dryland water supply system: The Karezes in Afghanistan, Iran, Pakistan, and the Kingdom of Saudi Arabia. Water International 33(3):333-349

International Organization for Migration (IOM) (2010) Kahriz Rehabilitation Project. http://www.iom.az/ projects/current/koica/, (Accessed January 2016)

Jansen M (1991) Mohenjo-daro - a city on the Indus. In: Jansen M, Mulloy M, Urban G (eds) Forgotten cities on the indus. Philipp von Zabern, Mainz, pp 145-165

Kahlown MA (2012) Pakistan. 276-344. In: Semsar Yazdi and Labbaf Khaneiki (eds.) Qanat in its cradle: Situation of Qanat in the world. International Center on Qanats and Historic Hydraulic Structures (UNESCO), Yazd

Khayyat AH (2009) Geographic information system (GIS) for Managing Karez (Qanat) resources. Paper presented at the Restoration and Maintenance of Karez in Iraq: advanced techniques in planning, methodology and applications workshop, International Center on Qanats and Historic Hydraulic Structures (ICQHS), Yazd, Iran, December 2009

Labbaf Khaneiki RA (2000) History of the qanat of Gonabad. In: Proceedings of the international symposium on Qanats, 1: 81-92. Yazd: Yazd Regional Water Authority (In Farsi)

Lansing JS (1987) Balinese "water temples" and the management of irrigation. American Anthropologist $89: 326-341$

Lawler A (2011) The world in between. Archeology 64:6

Lenk M, Mehdiyev R (2013) Melekli Kahriz-the first new construction of a fully functional Qanat in the Caucasus region in the 21 st Century. In: Proceedings of the first IWA workshop on traditional qanats technologies, Marrakech, Morocco, 24-26 October, 2013

Lightfoot DR (1996a) Moroccan Khettara: traditional irrigation and progressive desiccation. Geoforum 27(2):261-273

Lightfoot DR (1996b) Syrian qanat Romani: history, ecology, abandonment. J Arid Environ 33:321-336 
Lightfoot DR (2009) Survey of infiltration Karez in Northern Iraq: history and current status of underground aqueducts. UNESCO Report IQ/2009/SC/RP/1. Paris: UNESCO. http://unesdoc.unesco.org/images/ 0018/001850/185057E.pdf, Accessed January 2016

Lightfoot DR (In press) Function, distribution, and history of old world Qanats. In Scarborough V (ed), Water history and humanity. UNESCO Publishing, Paris

Magee P (2005) The chronology and environmental background of Iron Age settlement in southeastern Iran and the question of the origin of the qanat irrigation system. Iranica Antiqua 40:217-231

Manuel MJ, Coningham RAE, Gillmore GK, Fazeli H (2014) Societal change and sustainability within the Central Plateau of Iran: an archaeological viewpoint. In: Sillitoe P (ed) Sustainable development: an appraisal from the Gulf Region. Berghahn, London, pp 38-61

McHugh R (2012) Rehabilitation and conservation of Karez systems in the Northern Governorates of Iraq. UNESCO (United Nations Educational, Scientific and Cultural Organization) Final Evaluation Report, 30 January 2012. UNESCO, Amman

Mostafaeipour A (2010) Historical background, productivity and technical issues of qanats. Water History 2(1):61-80

Semsar Yazdi AA (2007) Exploitation of groundwater in Iran from the last century to the present. In: 5th IWHA conference, pasts \& futures waters, 13-17 June 2007. Tampere

Semsar Yazdi AA, Askarzadeh S (2007) A historical review on the Qanats and historic hydraulic structures of Iran since the first millennium B.C. International history seminar on irrigation and drainage, 2-5 May 2007. Tehran

Semsar Yazdi AA, Labbaf Khaneiki M (2012a) Azerbaijan. 43-74. In: Semsar Yazdi and Labbaf Khaneiki (eds) Qanat in its cradle: situation of Qanat in the world. International Center on Qanats and Historic Hydraulic Structures (UNESCO), Yazd

Semsar Yazdi AA, Labbaf Khaneiki M (2012b) Qanat in its cradle: situation of Qanat in the world. International Center on Qanats and Historic Hydraulic Structures (UNESCO), Yazd

Semsar Yazdi AA, Labbaf Khaneiki M (2012c) Iran. 75-147. In: Semsar Yazdi and Labbaf Khaneiki (eds) Qanat in its cradle: situation of Qanat in the world. International Center on Qanats and Historic Hydraulic Structures (UNESCO), Yazd

Shobair SS2012. Afghanistan. 21-42. In: Semsar Yazdi and Labbaf Khaneiki (eds) Qanat in its cradle: situation of Qanat in the world. International Center on Qanats and Historic Hydraulic Structures (UNESCO), Yazd

Staubwasser M, Weiss H (2006) Holocene climate and cultural evolution in late prehistoric-early historic West Asia. Quatern Res 66:372-387

Strikker C, Olsthoorn T, Jaait M, Hilali M (2013) A Groundwater Model Attempt for the Khettara Area Fezna-Jorf-Hannabou. Proceedings of the First IWA workshop on traditional Qanats technologies, Marrakech, Morocco, 24-26 October, 2013

United Nations Food and Agriculture Organization (UNFAO) (2014) Qanat Irrigated Agricultural Heritage Systems. United Nations Food and Agriculture Organization. http://www.fao.org/fileadmin/templates/ giahs/Presentations/april2014sc/05/iran_giahs_2014_rome-Final.pdf, Accessed January 2016)

Walker RT, Fattahi M (2011) A framework of Holocene and Late Pleistocene environmental change in eastern Iran inferred from the dating of periods of alluvial fan abandonment, river terracing, and lake deposition. Quatern Sci Rev 30:1256-1271

Walker RT, Talebian M, Sloan RA, Rasheedi A, Fattahi M, Bryant C (2010) Holocene slip-rate on the Gowk strike-slip fault and implications for the distribution of tectonic strain in eastern Iran. Geophys $\mathbf{J}$ Int 181(1):221-228

Walther C (2011) Rehabilitation and conservation of Karez systems in the Northern Governorates of Iraq. UNESCO (United Nations Educational, Scientific and Cultural Organization) External Evaluation Report. UNESCO, Amman

Weiss H (2000) Beyond the younger Dryas collapse as adaptation to abrupt climate change in ancient west Asia and the eastern Mediterranean. In Bawden G, Reycraft R (eds) Confronting disaster: engaging the past to understand the future. University of New Mexico Press, pp 75-98

Weiss H, Courty MA, Wetterstorm W, Guichard F, Senior L, Meadow R, Curnow A (1993) The genesis and collapse of third millennium north Mesopotamia civilisation. Science 261:995-1004

Wessels J (2008) Collective action for rehabilitation of traditional water tunnel systems (Qanats) in Syria. Amsterdam University Press, Amsterdam

Wilkinson TJ, Boucharlat R, Ertsen MW, Gillmore G, Kennet D, Magee P, Rezakhani K, De Schacht T (2012) From human niche construction to imperial power: long-term trends in ancient Iranian water systems. Water History 4(2):155-176

Wittfogel K (1956) The hydraulic civilisations. Chicago University Press, Chicago 
Wittfogel K (1957) Oriental despotism: a comparative study of total power. Yale University Press, New Haven

Wossink A (2009) Challenging Climate Change: Competition and Cooperation Among Pastoralists and Agriculturalists in Northern Mesopotamia (c.3000-1600 BC). Sidestone Press, Leiden

WWAP (World Water Assessment Programme) (2012) The United Nations World Water Development Report 4: Managing Water under Uncertainty and Risk. UNESCO, Paris

Mark Manuel is a Research Fellow attached to the UNESCO Chair in Archaeological Ethics and Practice in Cultural Heritage. He is a landscape archaeologist who has worked in India, Sri Lanka, Nepal, Bangladesh, Iran and Egypt. His research interests include the development and role of non-urban communities, the development of early urbanism, and archaeological survey methodologies.

Dale Lightfoot's research relies on fieldwork involving historic landscapes, agriculture and water technology, and themes which emphasize human-environment relationships. He has authored or co-authored more than 50 publications and has worked in or traveled through more than 130 countries. Funded research has taken him to the southwest U.S.A, Central Asia (Uzbekistan, Tajikistan, Kazakhstan), Spain/Canary Islands, Morocco, Tunisia, Cyprus, and the Middle East (Jordan, Syria, Yemen, Iraq). He has also led field courses or engaged in professional outreach activities in Morocco, Iraq, Iran, Azerbaijan, Vietnam, Mexico, Cuba, and several countries in Central America. Since 1992 he has conducted comprehensive, country-wide surveys of qanats in Morocco, Tunisia, Spain, Cyprus, Syria, Jordan, Iraq, Yemen, and Uzbekistan. He received his Ph.D. in Geography in 1990 at the University of Colorado-Boulder. He has served on the faculty at the University of Colorado-Denver, Old Dominion University (Virginia), and Oklahoma State University.

Morteza Fattahi is an associate professor of Geophysics at the University of Tehran, Iran. His research focuses on the luminescence dating and its applications in paleoseismology, paleoclimatology and archaeology in Iran. 